\title{
Brazilian national curriculum guidelines for the undergraduate nursing course: ABEn's fight against setbacks
}

\author{
Edlamar Kátia Adamy' \\ ORCID: 0000-0002-8490-0334 \\ Josicelia Dumêt Fernandes ${ }^{11,} \mathrm{x}$ \\ ORCID: 0000-0003-2946-5314 \\ Danielle Christine Moura dos Santos ${ }^{11,}, x$ \\ ORCID: 0000-0001-9711-4431 \\ Mara Regina Lemes De Sordi ${ }^{1 \mathrm{v}, x}$ \\ ORCID: 0000-0003-1216-7185 \\ Flávia Regina Souza Ramos ${ }^{v, x}$ \\ ORCID: 0000-0002-0077-2292 \\ Kênia Lara da Silva ${ }^{\mathrm{vl}, \mathrm{x}}$ \\ ORCID: 0000-0003-3924-2122 \\ Maria Lucélia da Hora Sales ${ }^{\mathrm{VI}, \mathrm{x}}$ \\ ORCID: 0000-0001-9697-8211 \\ Helen Campos Ferreira ${ }^{\text {VIII, } x}$ \\ ORCID: 0000-0001-6383-5839 \\ Francisca Valda da Silva' ${ }^{1 x, x}$ \\ ORCID: 0000-0002-6364-2241
}

' Universidade do Estado de Santa Catarina. Director of Education at ABEn Nacional. Chapecó, Santa Catarina, Brazil.

"Universidade Federal da Bahia. Salvador, Bahia, Brazil. I' Universidade de Pernambuco. Recife, Pernambuco, Brazil.

"Universidade Estadual de Campinas. Campinas, São Paulo, Brazil.

Universidade Federal da Santa Catarina. Visiting Professor at Universidade do Estado do Amazonas, Manaus, Amazonas. Florianópolis, Santa Catarina, Brazil.

${ }^{v}$ Universidade Federal de Minas Gerais. Belo Horizonte, Minas Gerais, Brazil.

VII Universidade Estadual de Ciências da Saúde. Maceió, Alagoas, Brazil.

VIII Universidade Federal Fluminense. Rio de Janeiro,

Rio de Janeiro, Brazil.

Ix Universidade Federal do Rio Grande do Norte. Natal, Rio Grande do Norte, Brazil.

${ }^{x}$ Member of the Permanent Graduate Committee of ABEn Nacional.

How to cite this article:

Adamy EK, Fernandes JD, Santos DCM, Sordi MRL, Ramos FRS, Silva KL, et al. Brazilian national curriculum guidelines for the undergraduate nursing course: ABEn's fight against setbacks. Rev Bras Enferm. 2021;74(6): e740601. https://doi.org/10.1590/0034-7167.2021740601
The Brazilian Association of Nursing (ABEn - Associação Brasileira de Enfermagem -Nacional), considering the provisions of its bylaws, with regard to nursing education in the Brazilian context, focused on the construction of the propositional draft for the Brazilian National Curriculum Guidelines for the Undergraduate Nursing Course (DCN/Nur - Diretrizes Curriculares Nacionais do Curso de Graduação em Enfermagem). This draft was built considering the Federal Constitution, the Laws and Resolutions that govern higher education and undergraduate health course in our country. For $A B E n$, it is essential to consider the demands for training in line with the population's health needs, advances in professional nursing practice, the commitment to consolidating the Unified Health System (SUS - Sistema Único de Saúde) and developing its competence as an organizer of the training of healthcare professionals in compliance with constitutional references.

It should be noted that the current DCN/Nur were approved in 2001, i.e., two decades ago. At that time, there was remarkable respect and consideration for the proposals emanating from fruitful experiences in the production of knowledge, knowledge and innovation in the professional practice of nurses in healthcare services and participation in the category. The need for reformulation was due to the recognition of health, social, political and cultural issues, which point to the alignment to a more contemporary context without losing its essence with regard to the historical trajectory of advances in nursing and health and its important contribution to the population's health, ensuring the social rights guaranteed in the constitution.

The draft/document was sent, in 2017, for consideration by the Brazilian National Health Council (CNS - Conselho Nacional de Saúde) and the Brazilian National Education Council (CNE - Conselho Nacional de Educação). This draft explicitly brings the values inherent to the profession and the training process, reaffirms the social role of nursing education and projects a broad, solid education with philosophical, technical and scientific bases capable of sustaining a competent professional practice, ethics and social commitment.

The debate and formulation of DCN/Nur, based on the draft sent by ABEn, advance and gain power and social legitimacy in the collective construction carried out within the scope of CNS in 2017, through its Intersectoral Committee on Human Resources and Labor Relations (CIRHRT - Comissão Intersetorial de Recursos Humanos e Relações de Trabalho), which resulted in CNS Resolution 573 of January 31, 2018, which approved CNS Opinion 28/2018 (1).

The communities that played a leading role in the construction of the draft remained attentive and interested in the speed of processing and approval of indicative proposal for changes in undergraduate nursing courses throughout the national territory. However, for various issues that go through the pandemic and even political decision, the agenda for the formulation of the new DCN/Nur has been extended within the scope of the Higher Education Chamber of CES/CNE, even if there were, at this time, $A B E n$ 's official requests to CNE for information about the progress and its interest in the process.

Three years after the draft was sent, only in 2021 was it guided by CNE. If the time gap in this return was not enough, the document deliberated 
by the Council presented profound changes in relation to the original draft that compromise the quality of nurses' education.

It is a proposal of DCN/Nur with concepts and fundamentals presented in a generic and superficial way, hiding core points and fundamental principles of inestimable value for the training of nurses and that are considered non-negotiable. The document adopts paths that depart from a socially referenced conception of quality in health education, disguising this intention by presenting concepts and categories, without specifically stating which meanings it intends to affirm. It does not justify the adoption of the philosophical theoretical model of training that goes back to the pedagogical methodology of transmission of knowledge that is not appropriate to the process of professional training for nurses.

The CNE proposal goes back to an instrumental, technical training by discarding contents of the ABEn and CNS proposal, which contemplate the technical, political and social commitment of nurses' training processes to meet the relevant participation of this professional in the expansion of the production of healthcare services for the population and in the processes of improvement of ethical, political and technically qualified performance.

From the point of view of education, the proposal presented hurts the meaning of education as a process of individual and social transformation, conveys the reductionist conception that training a professional is simply offering a course, a collection of content, without rooting in the world of work, in reality and in the larger commitments to society.

Thus, the proposal presented by CES/CNE weakens the training of new generations of nursing workers, with a strong impact on the quality of the healthcare model and on SUS as a universal access system.

\section{REFERENCES}

1. Ministério da Saúde (BR). Resolução n. 573, de 31 de janeiro de 2018. Aprovar o Parecer Técnico n. 28/2018 contendo recomendações do Conselho Nacional de Saúde (CNS) à proposta de Diretrizes Curriculares Nacionais (DCN) para o curso de graduação Bacharelado em Enfermagem. Available from: https://conselho.saude.gov.br/resolucoes/2018/Reso573.pdf 